\title{
FEATURES OF THE DEVELOPMENT OF FINANCIAL POLICY OF RUSSIAN COMPANIES IN MODERN CONDITIONS
}

\author{
Igor Keri
}

Elena Gromova

\author{
Nadezhda Sinelschikova \\ Plekhanov Russian University of Economics, Moscow, Russia
}

The study includes proposals regarding the development of rational financial policies by Russian companies in modern conditions. The authors have identified the following areas of difficulty: sales, the deficit and availability of financial resources and investment for development and distribution, instability of external conditions.

Changes in price policies, optimization of components and volume of trade receivables accounts are some of the suggested ways of improving a company's sales. The solution to the lack of financial resources for a company's investment development can be determined by selecting the more effective forms of financing. The authors point out the limitations of investment activities financing under conditions of import substitution while suggesting a composition of indicators of innovation activity. The study states that the state faces the challenge of creating favourable conditions for improving the financial stability of companies. The authors suggest measures aimed at perfecting the mechanisms of governmental financial policies.

Keywords: pricing policy, commitment management, investment resources, dividend policy, innovation indicators, government regulation

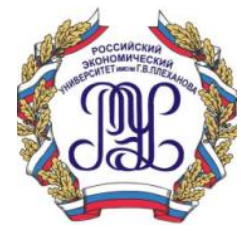

\section{Igor Keri}

Ph.D. is an Associate Professor in Economics at the Department of Financial Management, Faculty of Finance, Plekhanov Russian University of Economics, Russia. His scientific interest is finance policy company, modern capital budgeting techniques, evaluation of strategic investment projects of private and state companies. He actively participated on international conferences, published 3 textbooks, participated in 5 microeconomic projects.

\section{Elena Gromova}

Ph.D. is an Associate Professor in Economics at the Department of Finance and Pricing, Faculty of Finance, Plekhanov Russian University of Economics, Russia. Her scientific interest is finance policy company, investment attractiveness of companies in connection with future growth opportunities and competitive advantages. She has actively participated on international conferences, published 7 textbooks and participated in 3 collective monographs. She actively participated in 10 microeconomic projects.

\section{Nadezhda Sinelschikova}

Ph.D is an Associate Professor in Economics at the Department of Financial Management, Faculty of Finance, Plekhanov Russian University of Economics, Russia. Her scientific interest is finance policy company, investment projects of private and state companies. 


\section{FEATURES OF THE DEVELOPMENT OF FINANCIAL}

\section{Introduction}

Implementation of a company's financial policy in practice is closely related to financial theory. At present, there is no systematic approach to the concept and formation of company's financial policy in financial theory. As a consequence, in real business practice most companies do not apply any holistic approach to the formation and implementation of financial policies, replacing it with disparate, and sometimes contradictory, managerial decisions in the field of financial management.

Categories "financial policy" and "financial management" should be highlighted here in the first place.

Financial policy is an independent concept, requiring a separate study and analysis in terms of both theory and practice.

Development and implementation of a financial policy by a company allows solving successfully its strategic and tactical tasks in comparison with the companies without a financial policy.

On a higher level, financial policy implemented by the state sets the vector for the formation of financial policies by all companies in the state (or in its specific region).

Directions of activities in the course of this research are put forward as follows:

to overview of the already available research \& development achievements in the field of company's financial policy;

to assess the impacts of internal and external challenges on the development of Russian companies in general;

to identify the key areas in the development of financial policies in terms of financial constraints.

The purpose of the study is to define a systematic approach to the contents of a company's financial policy for practical use in creating an effective financial management system.

The objectives of this study, taking into account the directions above, are as follows:

to determine the contents of a company's financial policy;

to develop recommendations on pricing policy, obligations of management, policy of attracting investment resources;

to justify potential state measures which should be aimed at creating favourable financial conditions for the development of Russian companies.

\section{Background}

Both globally and within Russian scientific community specifically, there has been a discussion as to the essence of a company's financial policy for quite a long time already. The following approaches to interpreting the scientific concept of "company's financial policy" have been identified by now: hierarchical, ideological, elemental, normative, managerial.

The hierarchical approach covers management of an economic entity from the perspective of different levels and is relatively rare in economic literature.

German scientist H. Hinterhuber (1996) considers "financial policy of an enterprise to be an element of strategic planning, which aims to increase the value of the enterprise through the implementation of operational and strategic plans". 
The ideological approach assumes that company's financial policy should be formed in accordance with its corporate ideology. This approach implies the establishment of company's development goals and tasks arising from them as well as the choice of methods to be used for their solution.

H. Ulrich (1990) adheres to the financial and economic model of company's policy, "the formation stages of which are the formulation of financial and economic goals, the identification of the enterprise's potential and the development of strategies for further development".

V. V. Bocharov (2014) defines financial policy as the course, purpose, strategy, ideology of the company.

Elemental approach studies the composition of elements that reflect the direction of financial policy of an organization.

M.V. Romanovsky (2014) refers to the elements of company's financial policy as: accounting policy, credit policy, cash management policy, cost management policy, dividend policy.

A.S. Makarov (2008) examines financial policy "in terms of the types of activities of the organization: investment, supply, production, marketing, innovation, financial etc.".

The normative approach implies the development of norms and principles for the functioning of economic entities in order to achieve the set goals.

Z. Bodie, R. Merton (2007) emphasize that under certain conditions "financial policy is to conduct ... a dividend policy that establishes, for example, a regularity in payments to shareholders in the form of dividends of one-third (or a different share) of profit". It is obvious that these authors perceive the terms "dividend" and "financial policy" in general as a set of principles and norms used in financial management.

Bertonesh M., Nait R. (2004) do not provide their own definition for financial policy. However, they specifically mention the target values (norm) for debt-to-equity and dividend ratios (in \%).

H.H. Hinterhuber (1996) defines policy as part of the strategic planning system and includes, as a direction of financial policy, "the choice of financial and economic criteria for evaluating development strategies and programs, as well as the contribution of individual units to increasing the market value of the enterprise".

Management approach is related to interpretation of company's financial policy as a set of activities (actions) for the purposeful formation and use of finance.

V.G. Kogdenko (2013) understands corporate financial policy as "a set of targeted actions for the effective formation and use of financial resources, focused on achieving the strategic and tactical goals of the corporation".

N.N. Simonenko and V. N. Simonenko (2017) consider financial policy to be a set of measures for purposeful raising, distribution and use of finance to achieve the objectives of an enterprise.

C. Drury (2005) in his work on management accounting addresses the importance of having the balance between correct structure of trade receivables account and its impact on company's activities as an integral part of financial policy.

In general, we can conclude that in economic specialized literature there is no uniform approach to the concept and the composition of company's financial policy. This prevents us from forming a complete understanding of this phenomenon as a whole. Moreover, many authors believe that financial policy and financial management are one and the same thing. 


\section{FEATURES OF THE DEVELOPMENT OF FINANCIAL}

As a consequence, no separate study is required for financial policy in theory and its formation and analysis in practice.

The authors of this study believe, however, that financial policy is subject to separate study and analysis, both in theory and in practice, in order to build an effective financial management system.

\section{Main Focus of the research}

The authors of the study consider it a practical necessity for any today's company to develop a financial policy which would cover all areas of financial management systematically in its operational, investment and financial activities.

Companies without a financial policy, that is, without systematised financial management, are unable to adequately take into account threats posed by changes in the external and internal environments, therefore, they are losing dynamism in their own development.

On the contrary, in companies that have a developed financial policy, a lot of attention is paid to monitoring factors and indicators of both external and internal environments. This allows taking into account the impact of specific factors and indicators while selecting the most optimal managerial decisions for certain areas of company's financial activities.

Attention to the investigated elements of financial policy enable companies respond quickly to serious economic challenges. The most significant challenge is currently the introduction of financial sanctions against Russia from the EU, the US and some other countries. The key consequence from such sanctions has been the deterioration of business climate, drastic changes in market conditions, increasing costs of doing business overall, reduced possibilities for attracting external and internal financial resources. Russian companies have been facing serious financial problems in such areas as sales, deficit and availability of financial resources for investment in own development and progress. The solution to all these problems directly concerns the improvements of companies' financial policies.

Selecting and monitoring the composition of financial indicators allows companies reasonably identify those areas of financial policy that require special attention at the moment. The following indicators have been selected for monitoring: the change in price indices, the dynamics and the ratio of trade receivables and payables accounts, the dynamics of external sources of investment in fixed assets, the volumes of loans, the change in average lending rates, the volume of foreign investments' inflow into Russian economy. The information base for this research has become the Federal State Statistics Service (Rosstat, in short) and the Bank of Russia.

We believe that companies, considering the current conditions, should pay special attention to their pricing policy. Price serves as the tool for resolving marketing and competitiveness issues.

Information about the level of prices for the production and distribution of electricity, gas and water is a significant factor shaping the pricing policy. Table 1 provides detailed information on price indices for the production and distribution of electricity, gas and water in the Russian Federation, intended for sale at the domestic market. 
Table 1. Price indices for production and distribution of electricity, gas and water in the Russian Federation, intended for sale at the domestic market

(Source: Russian statistical yearbook, 2017)

\begin{tabular}{|c|c|}
\hline Year & Price index, in $\%$ \\
\hline 2006 & 110,3 \\
\hline 2007 & 113,3 \\
\hline 2008 & 118,0 \\
\hline 2009 & 118,3 \\
\hline 2010 & 113,8 \\
\hline 2011 & 105,1 \\
\hline 2012 & 107,0 \\
\hline 2013 & 108,1 \\
\hline 2014 & 104,5 \\
\hline 2015 & 109,3 \\
\hline 2016 & 105,1 \\
\hline
\end{tabular}

The data in Tab. 1 shows that during 2006-2016 there was a decrease in the growth of the price index in the production and distribution of electricity, gas and water, intended for sale domestically.

Solution of the current sales issues is largely dependent on how effective are the ongoing activities related to management of accounts receivable and creditor debt, explicitly associated with it. The state of trade receivables accounts has a direct impact on company's profitability. Comparative analysis of the dynamics of a company's accounts receivable and payable allows us identify the problems of selling products and making payments (Table 2).

Trade receivables account management is aimed at decreasing its growth rate while increasing the volume of working capital. The dynamics of trade receivables accounts of Russian companies is demonstrated in Tab. 2.

Looking at the data provided in Tab. 2, one can notice the trend of constant growth in the volumes of trade receivables accounts of Russian companies, including overdue debts. The growth in the volume of trade receivables results in the growing need to borrow more and more of capital, thus increasing costs and reducing profitability of a company. Eventually, this may lead to company's bankruptcy.

Trade payables are one of the sources for financing of current activities carried out by Russian companies. The share of trade payables accounts varies between $40-50 \%$ of the total liabilities of Russian companies. As to the structure of trade payables accounts, about $50 \%$ is accounted for by debts to suppliers and contractors. This situation has been prevailing for quite a long period of time by now and thus has already become a trend. 


\section{FEATURES OF THE DEVELOPMENT OF FINANCIAL}

Comparative analysis of the above indicators for Russian companies in general indicates that in the recent years the volumes of trade payables exceed trade receivables and this trend is growing all the time. This is yet another evidence that Russian companies are rather financially unstable.

In Order to obtain more complete information about the state of trade payables accounts, it is necessary to analyze the companies' turnover too. Comparison of the terms of turnover of trade payables and receivables accounts of Russian companies by main types of economic activity is presented in Tab. 3.

Table 2. The ratio of trade payables and receivables accounts, bln Rubles (Source: Region of Russia. Socio-economic indicators. Statistical compendium, 2017)

\begin{tabular}{|c|c|c|c|c|c|c|}
\hline$\underset{\nu}{\Xi}$ & 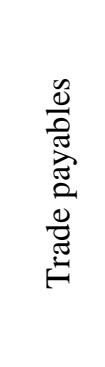 & 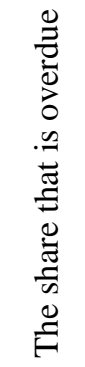 & 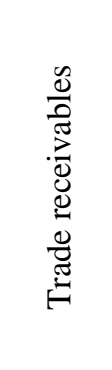 & 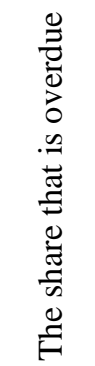 & 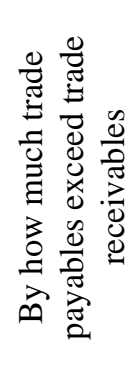 & 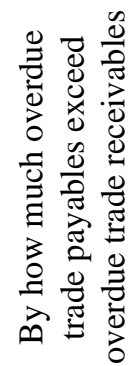 \\
\hline 2006 & 7697 & 821 & 7871 & 1040 & -174 & -219 \\
\hline 2007 & 10653 & 833 & 11061 & 887 & -408 & -54 \\
\hline 2008 & 13353 & 994 & 13783 & 1051 & -430 & -57 \\
\hline 2009 & 14882 & 958 & 15442 & 1011 & -560 & -53 \\
\hline 2010 & 17683 & 1006 & 18004 & 1048 & -321 & -42 \\
\hline 2011 & 20954 & 1208 & 21797 & 1167 & -843 & 41 \\
\hline 2012 & 23632 & 1188 & 22867 & 1225 & 765 & -37 \\
\hline 2013 & 27532 & 1470 & 26264 & 1483 & 1268 & -13 \\
\hline 2014 & 33174 & 1881 & 31014 & 2016 & 2160 & -135 \\
\hline 2015 & 38925 & 2429 & 35736 & 2276 & 3189 & 153 \\
\hline
\end{tabular}

With a slower turnover of trade payables in comparison with trade receivables, the former fully covers receivables and, moreover, serves as the source of financing for other elements of current assets. As a consequence, companies' liquidity and solvency are increasing.

But the risk of financial instability still increases. The Indicators of turnover by industry point at the existence of problematic issues in the regulation of accounts receivable, inter alia. 
Solving strategic-level directly related to companies' transition to new technological structures means, in the first place, providing companies with a sufficient volume of investment resources. Analysis of indicators on the state of external investment resources, taking into account constant and long-term lack of own funds, allows determining the likelihood of solving these tasks. 1.

Data on the structure of investment resources of Russian companies is presented in Fig.

Currently, there is a decrease in the share of external sources in financing of investment activities in the total volume of financial resources of companies. This is despite the trend being a continuous decline in profits for many companies and further ageing of fixed assets.

Table 3. Average maturity (turnover) of payables and receivables of companies by types of economic activity

(Source: Region of Russia. Socio-economic indicators. Statistical compendium, 2017)

\begin{tabular}{|c|c|c|c|c|c|c|c|c|c|c|c|c|c|c|c|c|c|c|}
\hline \multirow[t]{2}{*}{ Year } & \multirow[b]{2}{*}{ 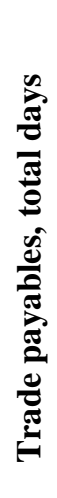 } & \multicolumn{8}{|c|}{ Including } & \multirow[b]{2}{*}{ 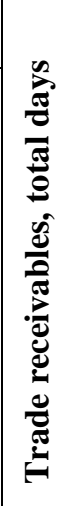 } & \multicolumn{8}{|c|}{ Including } \\
\hline & & . & 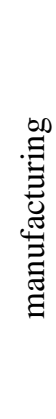 & 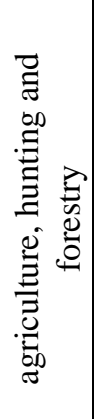 & 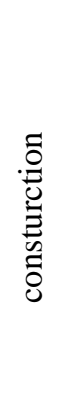 & 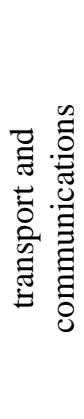 & 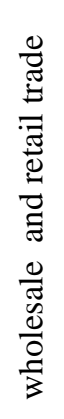 & 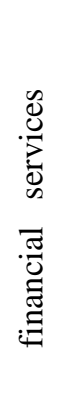 & 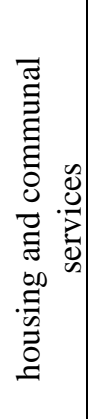 & & 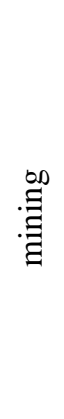 & 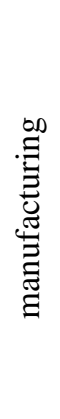 & 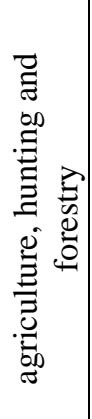 & 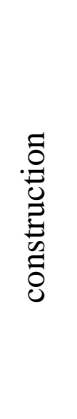 & 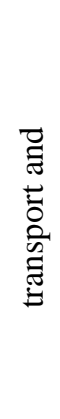 & 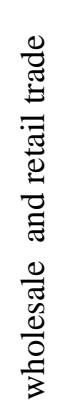 & 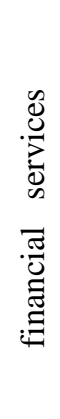 & 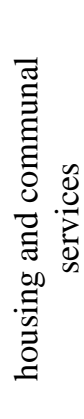 \\
\hline 2006 & 60 & 75 & 50 & 88 & 102 & 55 & 51 & 37 & 132 & 54 & 52 & 51 & 60 & 80 & 45 & 55 & 35 & 89 \\
\hline 2007 & 59 & 47 & 52 & 80 & 112 & 54 & 59 & 31 & 112 & 59 & 53 & 56 & 00 & 91 & 46 & 62 & 29 & 84 \\
\hline 2008 & 65 & 51 & 56 & 79 & 138 & 56 & 58 & 49 & 95 & 63 & 58 & 58 & 73 & 104 & 48 & 61 & 45 & 77 \\
\hline 2009 & 76 & 62 & 74 & 87 & 177 & 51 & 61 & 55 & 104 & 72 & 69 & 74 & 80 & 131 & 41 & 63 & 59 & 91 \\
\hline 2010 & 66 & 53 & 71 & 83 & 170 & 59 & 64 & 13 & 102 & 63 & 62 & 69 & 81 & 124 & 49 & 63 & 16 & 92 \\
\hline 2011 & 68 & 52 & 68 & 80 & 173 & 65 & 59 & 13 & 106 & 67 & 58 & 69 & 86 & 120 & 57 & 73 & 17 & 97 \\
\hline 2012 & 75 & 61 & 68 & 198 & 184 & 65 & 60 & 19 & 113 & 70 & 66 & 65 & 104 & 128 & 55 & 67 & 28 & 108 \\
\hline 2013 & 75 & 71 & 76 & 87 & 152 & 70 & 65 & 12 & 133 & 68 & 80 & 73 & 94 & 100 & 56 & 68 & 16 & 150 \\
\hline 2014 & 81 & 68 & 79 & 80 & 235 & 71 & 71 & 23 & 148 & 74 & 80 & 79 & 88 & 165 & 51 & 66 & 27 & 170 \\
\hline 2015 & 80 & 65 & 89 & 78 & 241 & 72 & 69 & 21 & 161 & 75 & 82 & 92 & 84 & 176 & 49 & 66 & 23 & 204 \\
\hline
\end{tabular}

It should be also noted that in developed countries, investment funds are mostly originating from company's own funds (profit and depreciation), which, if necessary, are supported by external sources - bank loans, bonded loans, other means (including the 


\section{FEATURES OF THE DEVELOPMENT OF FINANCIAL}

issuance of shares). So, on average in the US industry, depreciation is about $60-70 \%$ of capital investment, being the main source of investment resources.

Fig. 1 shows that the share of bank loans in the total volume of main capital investments is traditionally low - from 8 to $10 \%$. Following a sharp increase in interest rates, lending volumes reached their peak at the end of 2014, after which they fell sharply in 2015 and still remain below the level of 2014 (Fig. 2).

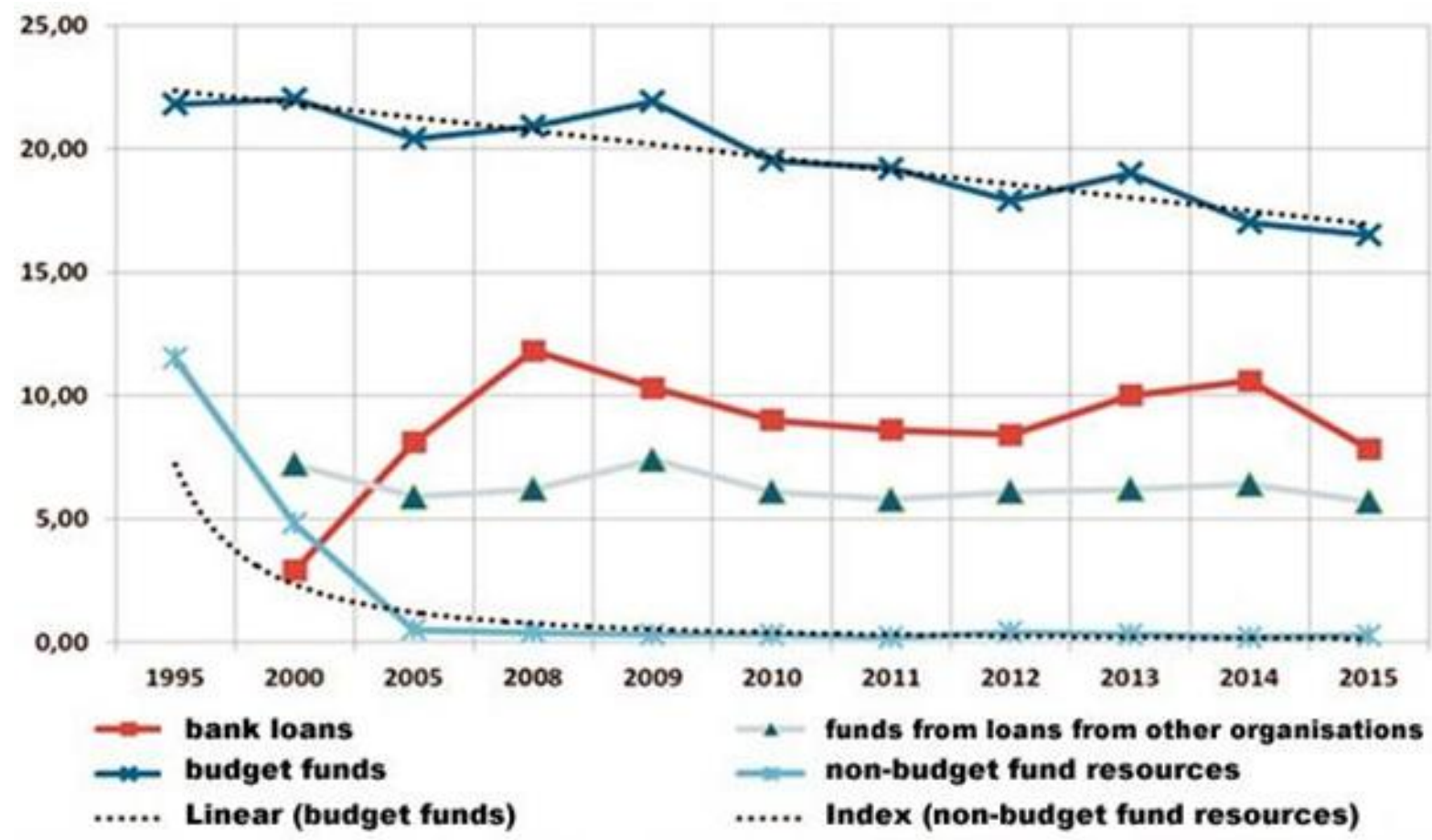

Figure 1. Dynamics of the main sources of external investments into main capital of Russian companies, in \%

(Made up by authors based on Federal State Statistics Service data)

High interest rates on loans are the major issue which is preventing fixed capital in Russia from being updated. In response to the sharp fall in the ruble exchange rate in December 2014, the Bank of Russia raised the base rate to $17 \%$ in order to stabilize the financial situation in the country. After that banks also significantly raised their rates on loans (see Fig. 3).

In January 2015, for non-financial organizations, the average weighted rates on ruble loans for the period up to a year reached $19.9 \%$, for over a year $-15.1 \%$. Stabilization of the financial sector led to gradual reduction in these rates: in September 2016, the Bank of Russia lowered the key rate to $10 \%$. At the same time, the rates of ruble loans for nonfinancial companies (12.7\% and $13.7 \%$ in June 2016 for loans with the maturity of less than and more than a year, respectively) still remain above the level of November $2014(12,0 \%$ and $12,6 \%$ accordingly). High interest rates on loans restrain investments of primarily small and medium-sized businesses that usually do not have access to other external sources of financing. 


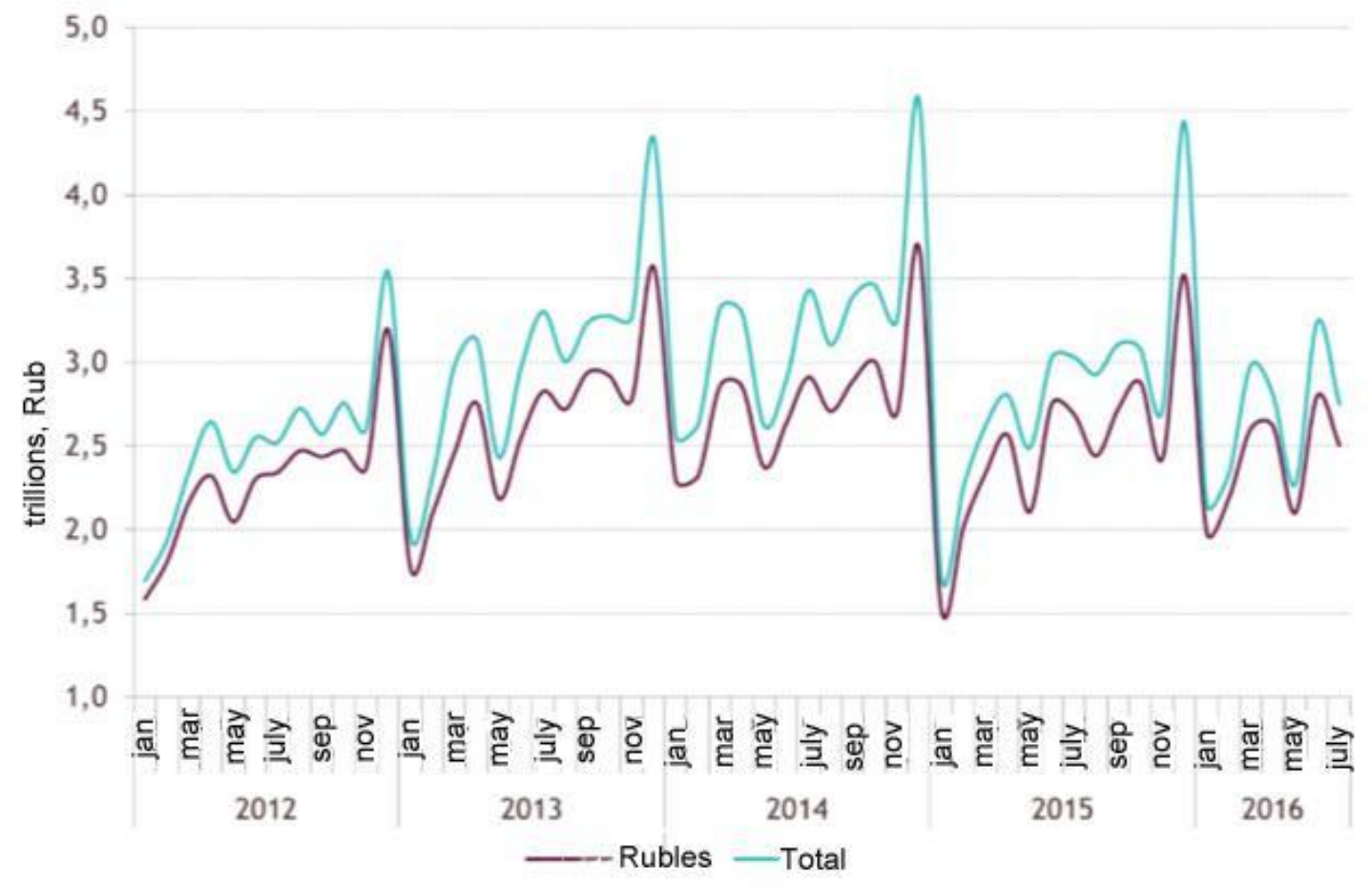

Figure 2. Change in volumes of loans provided to legal entities and individual entrepreneurs, 2012-2016, in current prices

(Made up by authors based on Bank of Russia data)

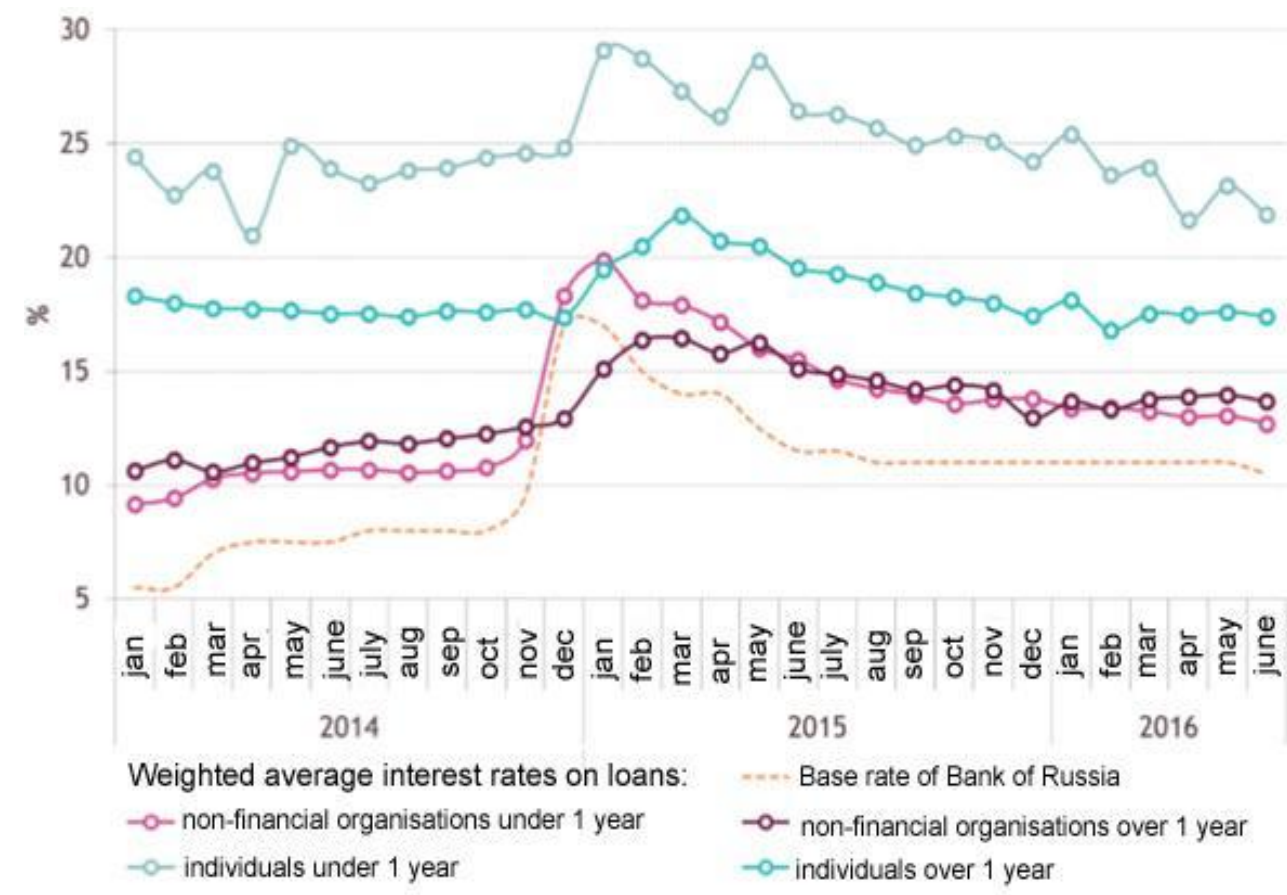

Figure 3. Weighted average interest rates on loans in rubles, 2014-2016 (in \%)

(Made up by authors based on Bank of Russia data) 


\section{FEATURES OF THE DEVELOPMENT OF FINANCIAL}

Understanding the possibility of attracting credit investment resources into Russian companies is a result of comparing average bank lending rates and profitability ratios of Russian companies (Tab. 4).

Table 4. Changes in profitability of Russian companies, in \%

(Made up by authors based on Russian statistical yearbook data)

\begin{tabular}{|c|c|c|}
\hline Year & Assets' profitability & $\begin{array}{c}\text { Profitability of sold goods, work and } \\
\text { services }\end{array}$ \\
\hline 2011 & 6,5 & 9,6 \\
\hline 2012 & 6,1 & 8,6 \\
\hline 2013 & 4,5 & 7,0 \\
\hline 2014 & 2,5 & 7,3 \\
\hline 2015 & 3,7 & 8,1 \\
\hline
\end{tabular}

Tab. 4 shows that the profitability of assets is decreasing. In the analyzed period, the profitability of assets decreased from $6.5 \%$ to $3.7 \%$. This indicates low return on invested capital. Decrease in the profitability of assets of Russian companies is also due to a decrease in profitability of sales.

Analysis shows that credit investment resources are unavailable for many Russian companies, since the average rates for these resources are much higher than the return on assets of companies.

The reduction in incoming direct investments in Russia by types of economic activity is shown in Fig. 4.

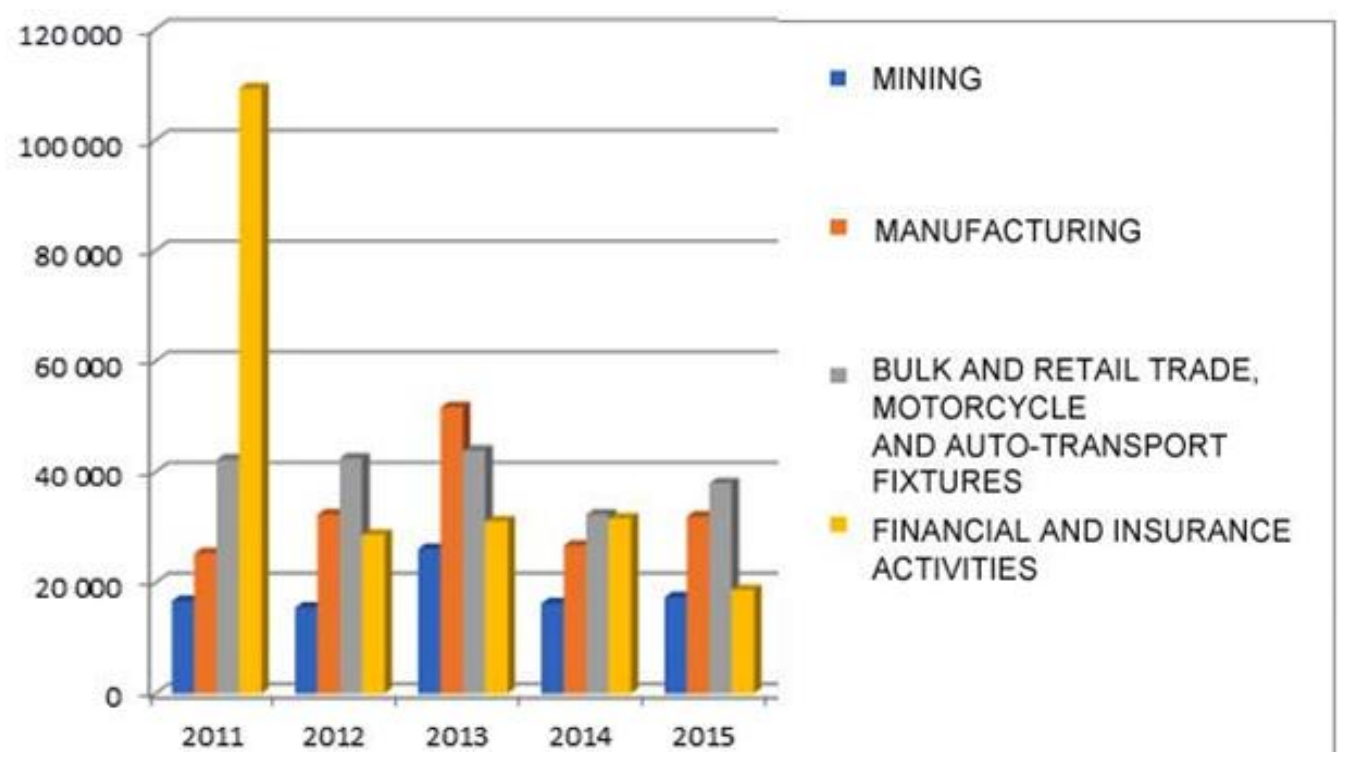

Figure 4. Direct investments in Russia in 2011-2015 by types of economic activity, mln USD

(Made up by authors based on Federal State Statistics Service data) 
Due to the introduction of sanctions against Russia by the EU, the United States and a number of other states, permanent investment inflows into Russian economy from these countries declined drastically. This caused major issues in areas, where foreign investments were supposed to be distributed. Foreign companies have stopped investing their capital in engineering, high-tech production and in automobile manufacturing. Under these conditions, many Russian companies were forced to roll back investment resources, which is especially observable in healthcare as well as the pharmaceutical industry.

Development and implementation of a financial policy by a company, within the framework of which a systematic approach is taken in analyzing the factors and indicators of the external and internal environments, will allow for a full and qualitative assessment of financial activities and identify areas that need to be improved. According to the results of the study, such areas are recognized as pricing policy, management of receivables and payables, investment and innovation policies.

The influence of direct or indirect factors investigated and indicators of external influence on financial policy (for example, indices of prices for the production and distribution of electricity, gas and water in the Russian Federation, intended for sale at domestic markets, weighted average rates for ruble loans) is carried out through certain state measures. The main directions of the state's actions directly related to companies' financial policy are: development of state tax policy, regulation of prices for natural monopolies, regulation of money supply and inflation, targeted state support for promising industrial projects, development of currency regulation and control system.

\section{Conclusion}

Stability and growth of country's economic development can be achieved through successful development of companies in the real sector, first of all. This can be realized through a flexible financial policy of companies which would allow more efficient and prompt managerial decisions in the field of finance.

The authors of this study consider it a practical necessity for all Russian companies to have a financial policy systematically covering all the areas of financial management. Proposals of the authors on such key areas of financial policy as pricing policy, commitment management, investment and innovation policies may enable Russian companies adequately respond to current external and internal challenges.

In the opinion of the authors, all state measures in the field of improving banking and tax policies, state regulation of prices for products of natural monopolies should be focused, first of all, on creating favourable conditions for business development.

Effective financial policy is the key prerequisite for successful operations within a company, competent investment decision-making, rational pricing and also for overcoming the cash deficit.

\section{References:}

Aliev, A.A. (2016). Methodological approach to assessing financial potential of innovation development using the example of the Socar oil and gas company. Economic Analysis: Theory and Practice ( 7), 153-161.

Bertonesh M., \& Nait R. (2004). Cash flow management. St. Petersburg, Piter Publ. 


\section{FEATURES OF THE DEVELOPMENT OF FINANCIAL}

Bodie Z. \& Merton R. (2007). Finance. Moscow, Williams Publ.

Bocharov V.V. (2008). Corporate finance. St. Petersburg, Piter Publ.

Doing Business (2017). Accessed from: http://www.doingbusiness.org/reports/globalreports/doing-business-2017

Drury K. (2005). Management and production accounting. Introductory course. Tutorial. Unity.

Gengher E. (2011). Best Practice in Accounts Receivable Reconciliation. Analytical report of Citi Group http://www.citigroup.com/transactionservices/home/about_us/articles/ docs/accounts_receivable.pdf

Global Venture Capital and Private Equity Country Attractiveness Index (2016). Accessed from: https://www.iese.edu/research/pdfs/ESTUDIO-143-E.pdf

Hinterhuber H. (1996). Strategische Unternehmensführung. Berlin; New York: Walter de Gruyter.

Memba S.F.,\& Dr. Njeru A. (2016). Effect of Accounts Receivable on Financial Performance of Firms Funded By Government Venture Capital in Kenya. Journal of Economics and Finance (IOSR-JEF), 7, 1, 62-69.

Kogdenko V.G. (2013). Corporate financial policy: features of development and implementation. Financial analytics: problems and solutions, (25), 2-13.

Makarov A.S. (2008). The financial policy of the organization, its types, instruments of formation and implementation. Finance and credit (10), 54-60.

Simonenko N.N. \& Simonenko V.N. (2017). Short-term and long-term financial policy of the firm: Textbook. M.: Master, SIC INFRA-M.

Romanovsky M.V. (2014). Corporate finance. St. Petersburg: Piter.

Ulrich H. (1990). Unternehmungspolitik. Bern, Stuttgart: Haupt.

Voronkova E.K. (2011). The balance of the economy and the investment policy of the Russian Federation. Business in law (06), 300-306.

Paper submitted

Paper accepted for publishing

Paper published online
12 February 2018

22 March 2018

31 July 2018 